Article

\title{
From Town to Countryside: Middle-Byzantine Bath-Houses in Eastern Crete and Their Changing Functions
}

\author{
Natalia Poulou* and Anastasios Tantsis \\ Department of Archaeology, School of History and Archaeology, Aristotle University of Thessaloniki, \\ Thessaloniki 54124, Greece; tassostan@hist.auth.gr \\ * Correspondence: npoulou@hist.auth.gr; Tel.: +30 2310997273
}

Received: 26 August 2018; Accepted: 10 September 2018; Published: 12 September 2018

check for updates

\begin{abstract}
The article examines the context of a recently discovered double bath-house complex in Loutres, a site near Mochlos on the north shore of eastern Crete. The excavators explore the broader questions posed by the finding, in connection to both its immediate surroundings and its wider periphery. Its relation to the site's geography, a ravine on the shore, forms the starting point to address issues regarding its original use as well as its later transformations. The enquiry leads into considering similar structures with different fates in the area and the connotations regarding their relationship to both the landscape and the settlements to which they belonged. The article goes on to discuss the general issues of the historic context of medieval Crete concerning both the archaeology and the information from the sources. It seems that long-held concepts about the abandonment of seaside settlements due to the so-called "Arab threat" are no longer valid. On the contrary, archaeology proves the continuity of the settlements of eastern Crete, both in Loutres and elsewhere. Moreover, the later use of the bath-houses in the area provides evidence for social changes after the 13th century impacting on both the landscape and its settlements.
\end{abstract}

Keywords: Byzantine bath-houses; medieval Crete; Byzantine settlements of eastern Crete; urban culture of Byzantium; church architecture; Secular Byzantine architecture; Byzantine Mochlos

\section{The Area of Research and the Excavation in Loutres}

Mochlos is a seaside settlement on the northern shore of east Crete (Figures 1 and 2). The site is famous for the Minoan settlement that was unearthed on a small islet just off its shore [1] (pp. 419, 442). Yet, in the area there is plentiful evidence for occupation and activity from different historic periods: on the shore, just across the island, there are rock-cut tanks for fish farming-vivaria dated to the Roman period $[2,3]$ (p. 17). On the island itself there are traces of a retaining wall extending along its higher northern part that has been dated to the Byzantine period. Another interesting structure found is a free-standing tower dated after the 7 th century $[4,5]$. 


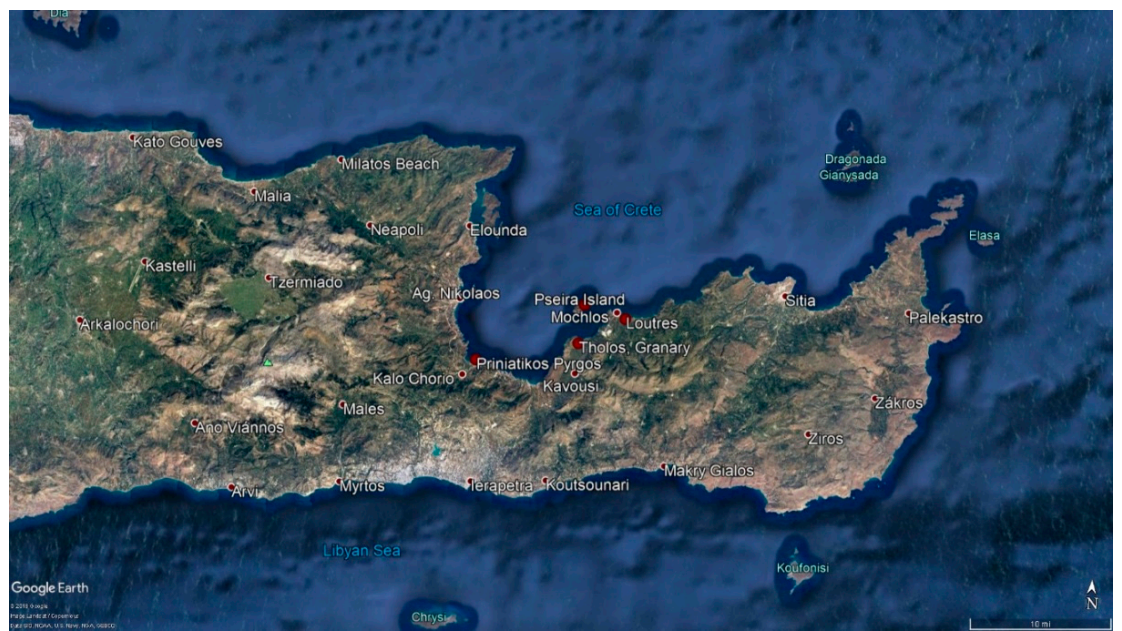

Figure 1. Map of Eastern Crete. (Source: Google Earth).

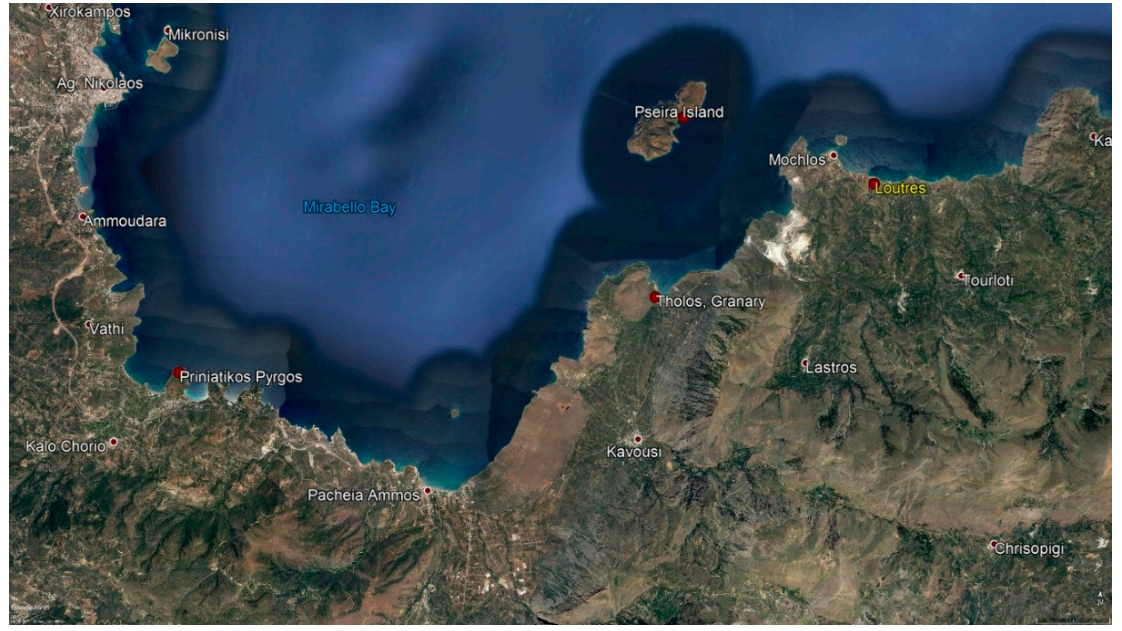

Figure 2. Map of Mochlos and its surrounds. (Source: Google Earth).

Less than a kilometer to the east of Mochlos, on top of a small hill and close to the shore, are remnants of a small basilica, probably of Late Antique date ([3] (pp. 17, 136); [6]). Some $200 \mathrm{~m}$ west of that, on a ravine between two hills, stands a cistern of medieval construction technology, ideally situated to collect and store water from the nearby stream (Figures 3 and 4). A cistern of similar technology and scale was found on the Byzantine settlement on Pseira Island (Figure 5).

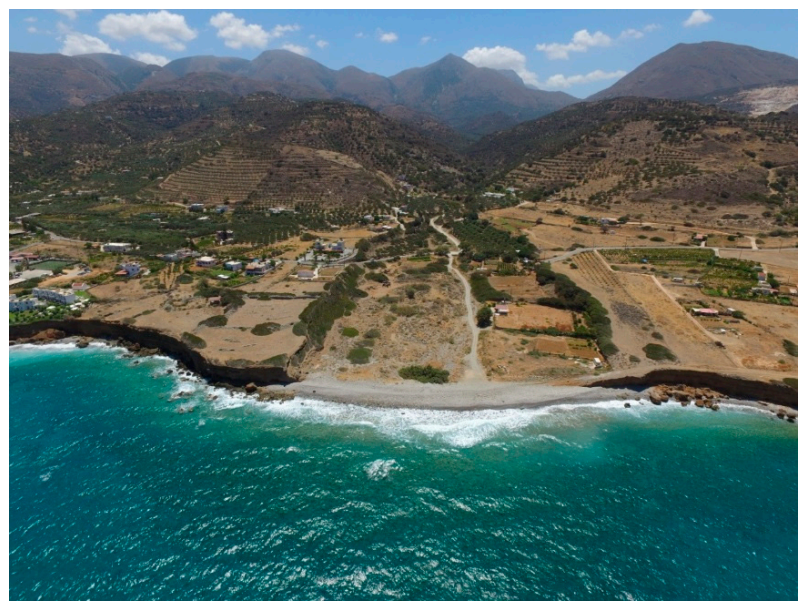

Figure 3. Aerial view of the site Loutres from the North. (Photo: Ph. Stefanou). 

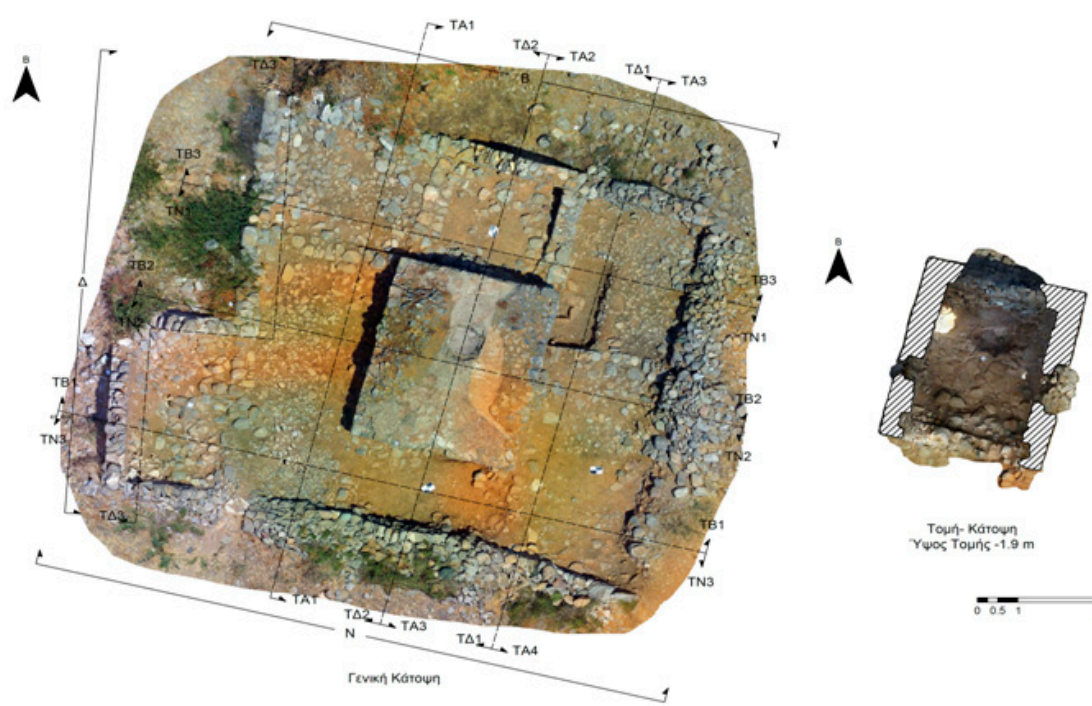

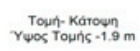

Figure 4. The cistern on the site Loutres, east of Mochlos, Siteia. (Orthophoto: Ph. Stefanou).

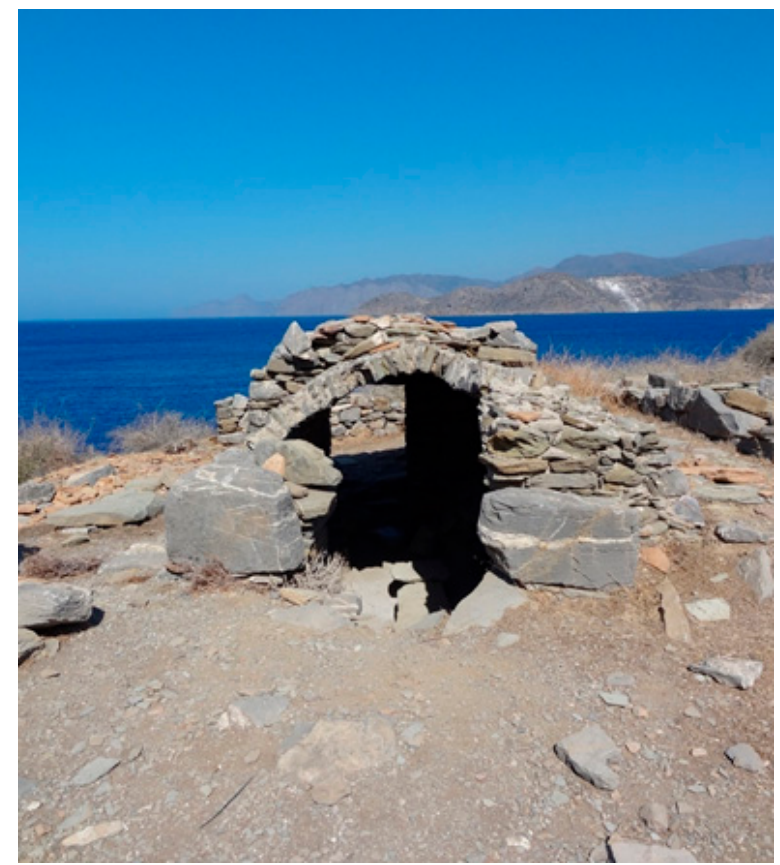

Figure 5. The cistern of the Byzantine settlement on Pseira island. (Photo: N. Poulou).

Nearly $20 \mathrm{~m}$ to the north of the cistern in Loutres we discovered and excavated a small cruciform vaulted structure of similar construction technology and scale that was clearly a bath-house $[6,7]$. Much to our surprise, a few meters to its northeast, we discovered yet another cruciform vaulted bath-house (Figure 6). Both structures are quite similar, although not identical, while it is clear from certain characteristics that both are bath-houses. The example to the southwest is in much better condition and has preserved evidence for its continuous use and for several later transformations: it seems that the structure underwent at least two building phases while functioning as a bath, although with several alterations in the second phase. Later, it was converted into a kiln for producing ceramics. Fairly recently, probably even in the 19th century, it was still in use, but by this time as a lime kiln, before it collapsed and was finally abandoned [6]. 


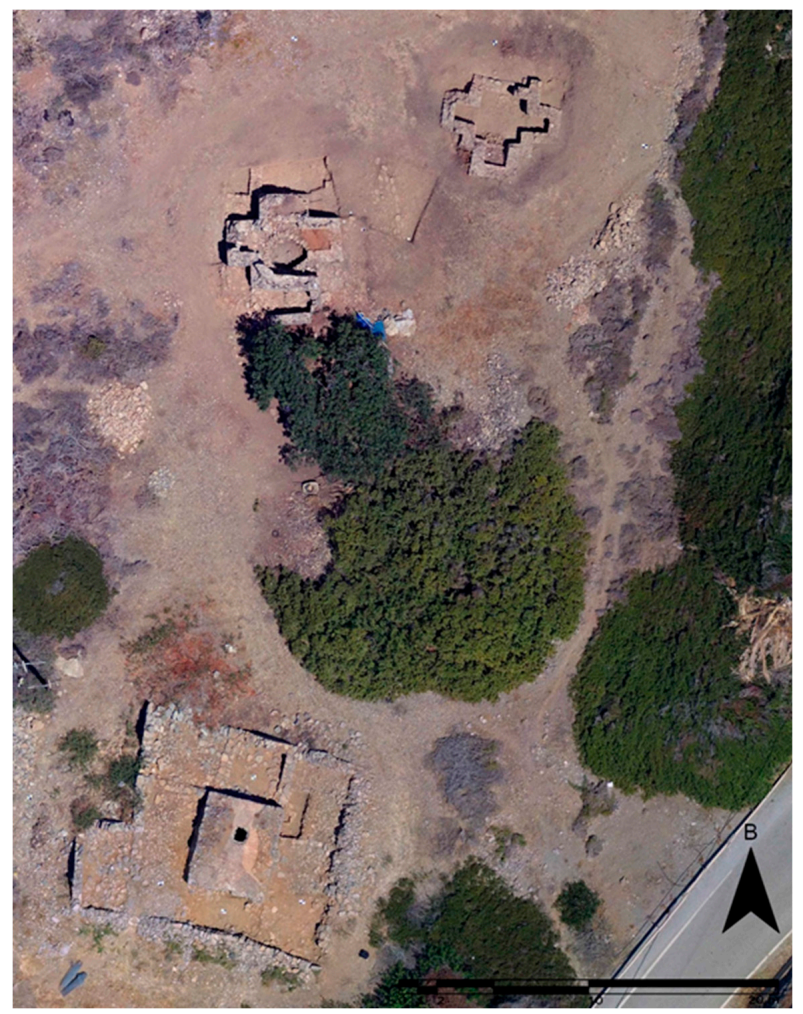

Figure 6. Aerial view/plan of the site in Loutres. From bottom: Building A (cistern), Building B (bath-house) and Building C (bath-house). (Orthophoto: Ph. Stefanou).

For both bath-houses, ceramic amphorae were used as air and water pipes, inserted into their walls (Figures 7 and 8). This vase type serves as a terminus post quem for the erection of the buildings: we identified the ceramic form as that of the so-called spatheia, small-sized amphorae imported from the area of Tunisia and dated from the mid-7th to the early 8th century [8] (pp. 127-129, fig, 69. 3B) (Figure 9). These offer evidence for dating the construction of the bath-houses sometime in the late 7th / 8th century. Both structures probably were used for bathing as late as the 12th century, when the first was turned into a workshop for producing ceramics.

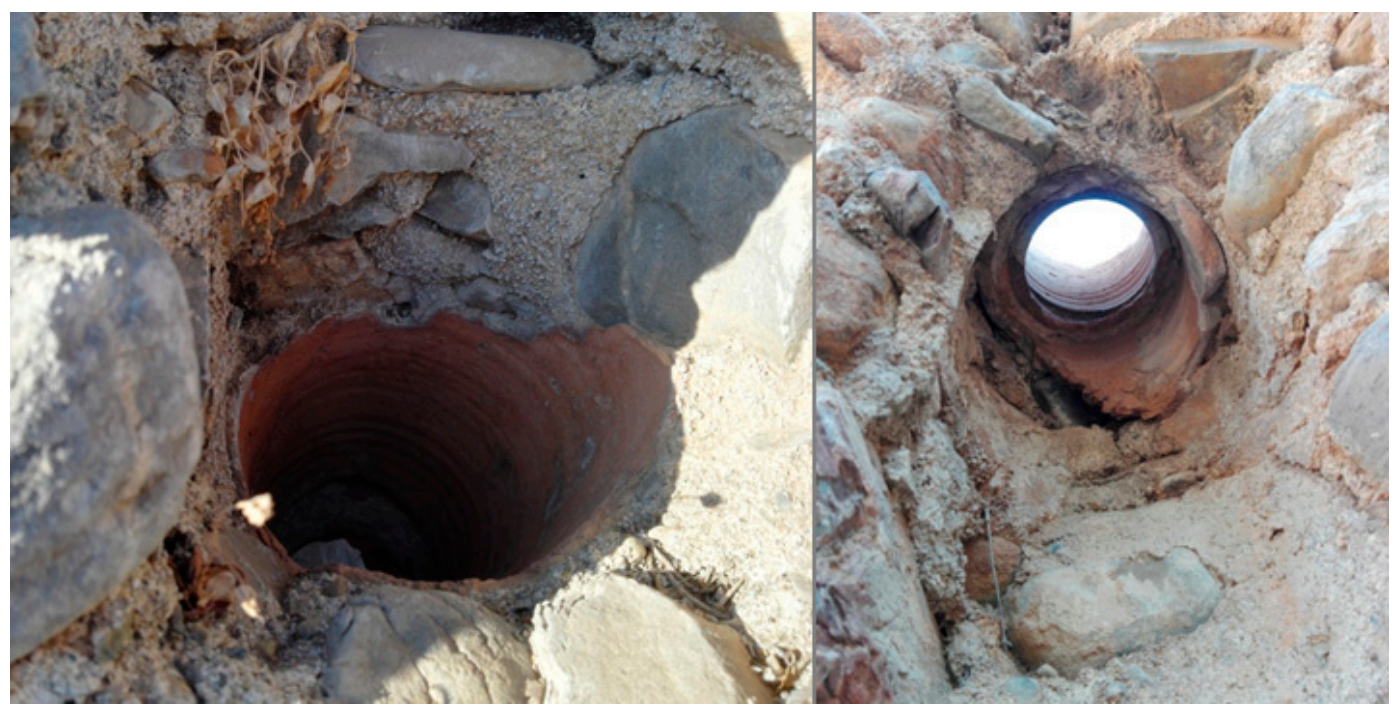

Figure 7. Amphorae deployed as air- and water-pipes in secondary use are found in both structures. (Photos: A. Tantsis). 


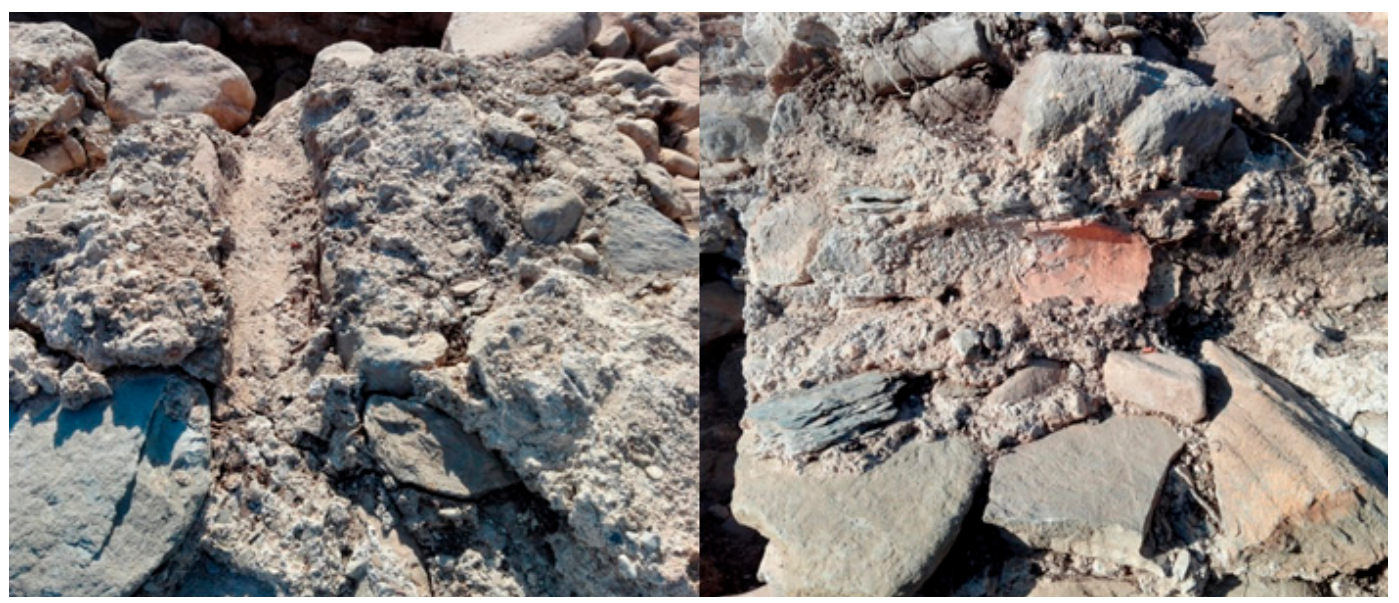

Figure 8. Detail of the positioning and remains of clay pipes (re-used amphorae) in Building C. (Photos: A. Tantsis).
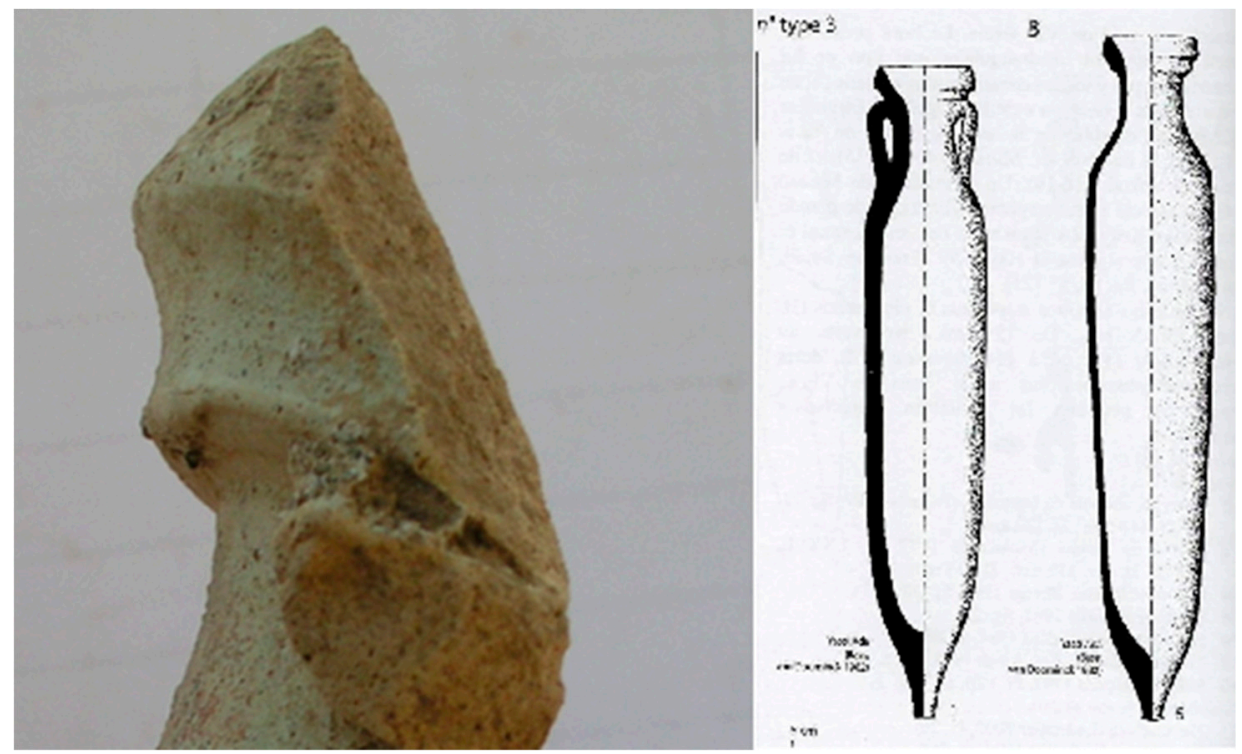

Figure 9. Fragments of amphorae (spatheia) re-used as air-pipe (Photo: N. Poulou). Same type as Bonifay 2004, 127-129, fig. 69, type 3B (shown on the right).

\section{The Loutres Bath-Houses and Their Broader Context}

The bathing complex we have uncovered in the locale known as Loutres, close to Mochlos, in east Crete, is very interesting for a variety of reasons (Figures 10-13). This paper will deal extensively with its setting both in the narrow sense and in a broader one. We will try to investigate the buildings' relationship to their environment and try to explore issues regarding functionality and the way they fit into the social and historic context of the transition of Crete from the early to the late middle ages. Our investigation will address issues of the transformation of urban culture in the transition from Late Antiquity to the Middle Ages and support the idea that towns and settlements continued functioning into the late Byzantine period. Our starting point is the bathing complex in Mochlos but the investigation will expand to include related issues concerning similar structures, mainly in eastern Crete (Figure 14). 


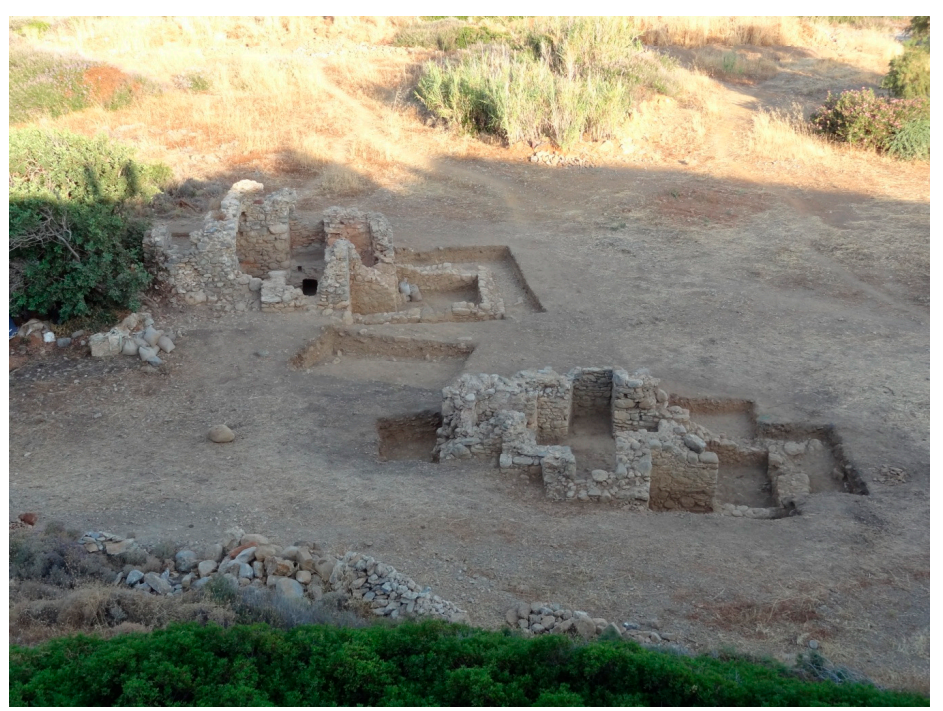

Figure 10. Building B and C (bath-houses) seen from the East. (Photo: N. Theodoridis).
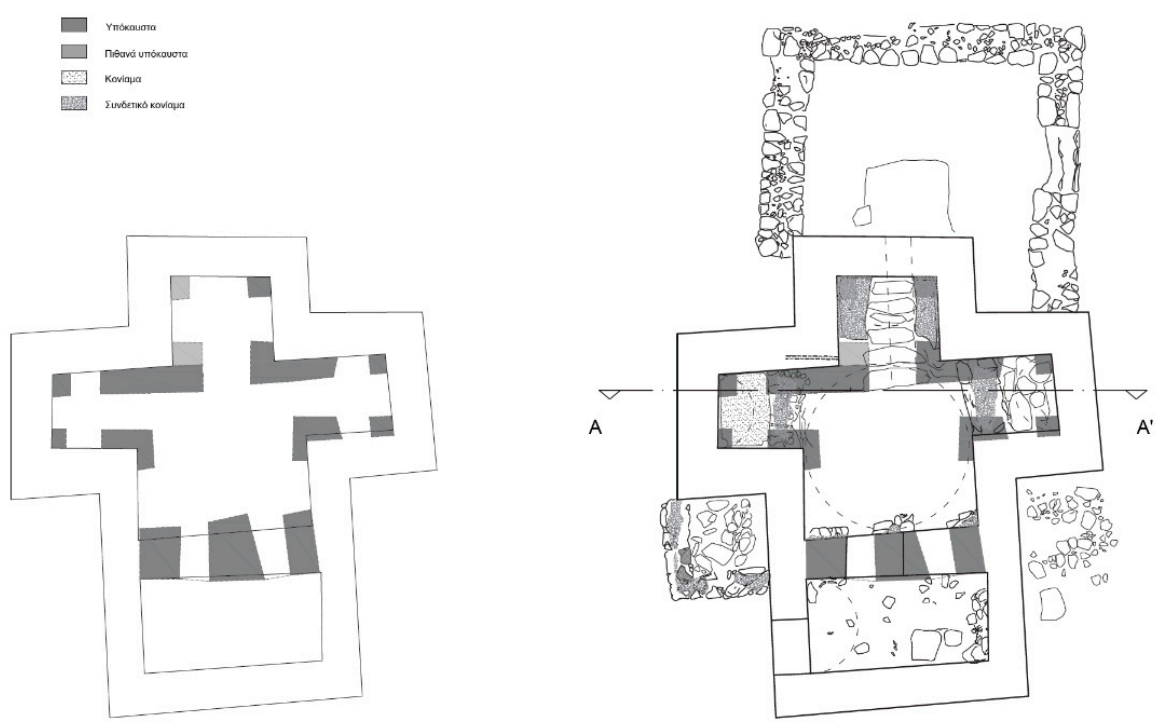

Figure 11. Two plans of Building B. The shaded area in the plan to the left represent the hypocaustal area, while the plan on the right includes adjacent structures. (Drawing: Th. Mangana).

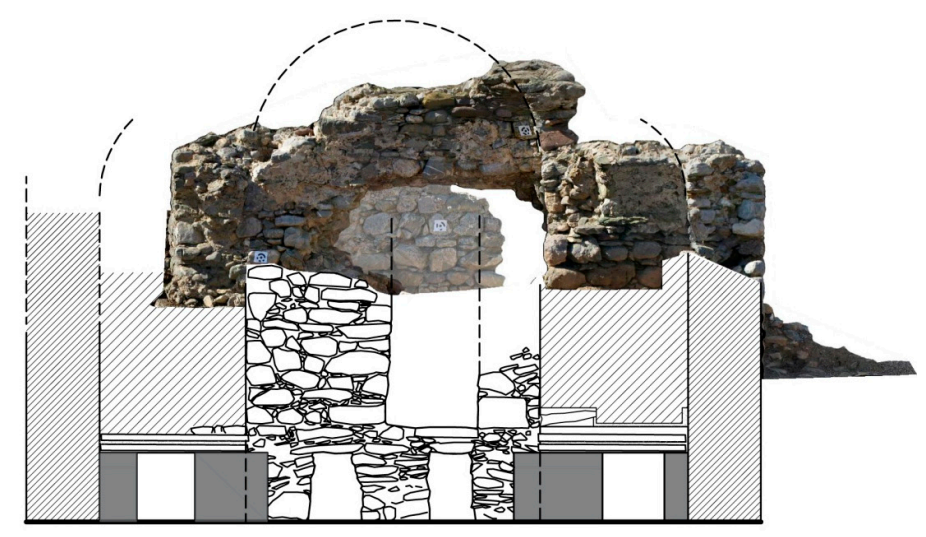

Figure 12. Elevation drawing of Building B, depicting the hypocaust and vault reconstruction. (Drawing: Th. Mangana). 


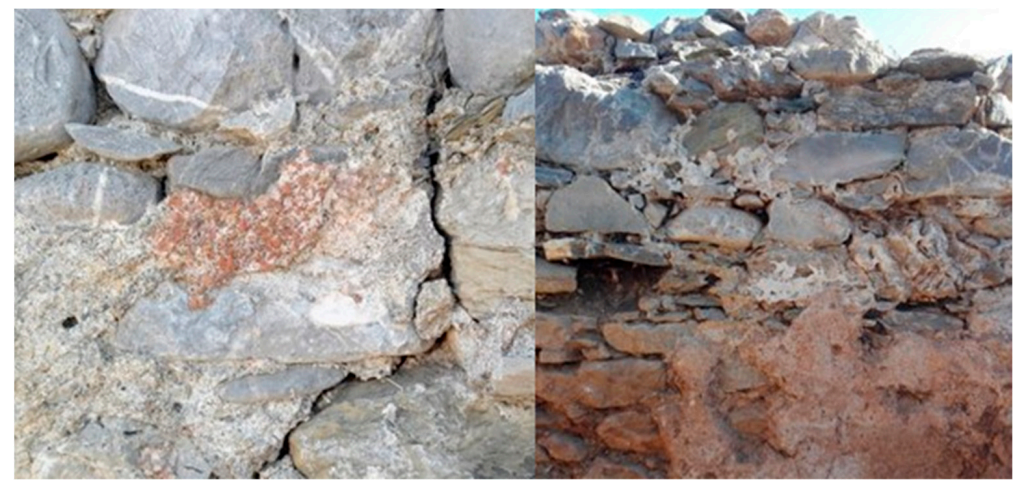

Figure 13. Details of hydraulic mortar covering both the outside and the inside surfaces at both bath-houses. (Photos: A. Tantsis).

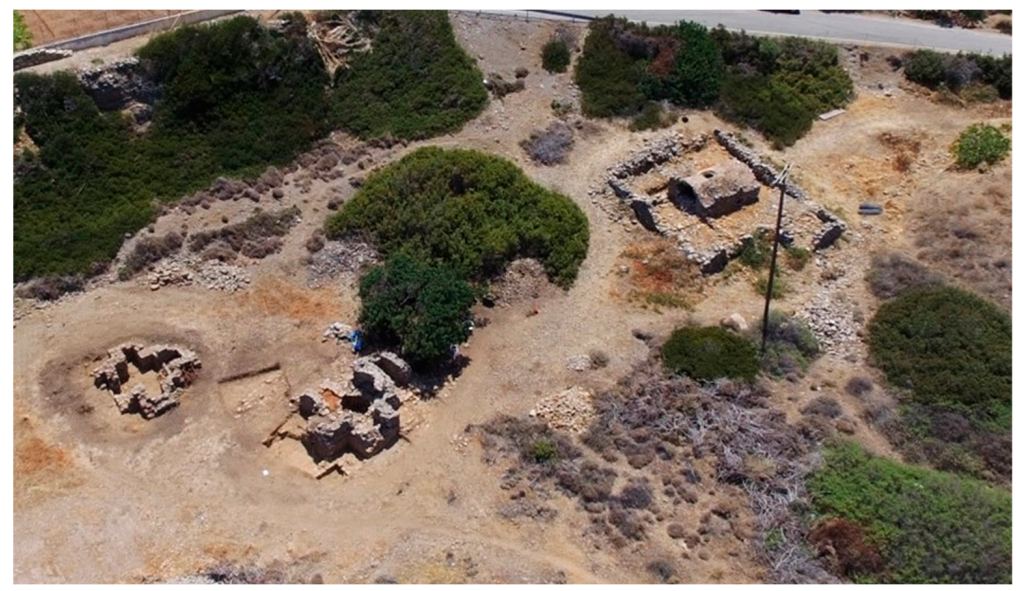

Figure 14. Aerial view of the cistern and the bath-houses on Loutres, from north-west. (Photo: Ph. Stefanou).

The archaeological investigation of the site is far from complete; in fact, we know very little regarding its context, both functionally and socially. On one hand, we lack, thus far, any evidence concerning the bath-houses' original surroundings. We can only suppose that both were part of a bigger building complex that was instrumental to their function. This complex could be extensive or small, yet it is quite plausible that these buildings were not isolated. It is feasible that these are the better preserved since they were constructed with more durable and water and fire-resistant materials, measures that contributed to their survival.

On the other hand, we know next to nothing regarding the complex's social context. Was it close to a settlement and, if so, what was its character?

Bathing as a social ritual has been associated with the urban life of the great or smaller cities of the Roman empire [9]. Nevertheless, there is plenty of evidence that bathing was commonly catered for with special structures both in towns and in the countryside. Throughout the Roman world, bath-houses operating in different social contexts varied in terms of scale, grandeur and overall luxury. These are the characteristics that distinguished bath-houses of the city from those of the countryside. The size, lavishness and technology of any bath-house are indications of the size and the resources of the community it served. Great Thermae are the hallmark of imperial patronage in the capital and certain imperially favored cities in the periphery. Lesser structures were scattered all over the empire, in cities, towns, villages and isolated residences, both in cities and far from them [10]. While scale has often been regarded as a distinguishing feature between public and private bath-houses, it is not an absolute indicator, and we should allow for hybrid installations.

A tendency to view bathing culture as a mainly urban phenomenon persists in modern scholarship; recent archaeological findings, however, have challenged this deeply-rooted assumption, 
broadening the narrative to include a more nuanced interpretation of the evidence. This urban reading still appears frequently in the literature discussing the manner in which bathing as a social activity, and bath-houses as public spaces, were impacted by the Christianization of Roman society, as can be seen in Yegül's recent bath-house study [9] (pp. 199-212).

The whole issue is complicated and is closely related to the way urban life and urban space was transformed due to its Christianization. It was long held that the great public bath-houses were abandoned following the large-scale adoption of Christianity. This was seen in connection to new moral codes and habits, prohibiting the exposure of nudity and any indulgence in physical pleasures. Yet it seems that changes in bathing habits are more of an indication of a shift in the economy's character than in its morals. From the 5th to the 6th century, public space was dominated by the Church, and its clerics and bishops seemed to occupy the role and functions of previous urban institutions that were no longer functioning or transformed. The church was all the more responsible for the upkeep of public amenities and thus minimized expenses allotted to functions that were previously lavishly catered for [11,12].

It is well known that bath-houses were still constructed, maintained, repaired and functioning long after the triumph of the Christian church. Moreover, public bath-houses were connected and operated by the Church as an institution. Bathing became more intimate; the whole ritual was shortened, and its architectural setting became smaller and less lavish. This might be an indication of moral strictness, yet there is a sense of a new ethos fitting an economy not supported by the state as well. In Philippi, in Macedonia, a former balneum with its own palestra was partially occupied by the octagonal church's baptistery [13]. The balneum became smaller but continued to function as a bath-house, most probably operated by the Church, since its main entrance seems to be near the atrium of the ecclesiastic building. In Kos, an inscription mentioning the restoration of a bath-house, overseen by the Hegoumenos of an apparently urban monastery, is a clear indication of the role of ecclesiastic dignitaries as caretakers for the city's public amenities [14]. In Byllis, the relatively large city acquired several churches, three of them on, or very close to, its center. Among them, a small public bath-house is connected to Justinian's care, through a detailed inscription, but nothing in its size or grandeur compares it to imperial thermae, its simplicity lies in striking contrast to the scale and lavishness of the contemporary churches all around it $[15,16]$.

Another interesting phenomenon is the conversion of bath-houses or their parts into churches [17]. This phenomenon, although extremely complicated both historically and archaeologically, seems to have strong roots in the perceptions about the Christianization of Roman society mentioned above. The hagiographical record endorses the view that in Thessaloniki, the basilica of Hagios Demetrios was built over a Roman bath-house (apparently a great public one) because in the literature, a bath-house served as the setting for the saint's imprisonment and execution. The team of the site's first excavations labelled the substructures of the present basilica as a Roman bath-house in which they also identified a martyrium, and this interpretation persists in modern literature [17] (pp. 160-162). Recent investigations and more scientific analysis of the evidence called into question the veracity of this claim, revealing a far more complex history of the architectural remains of the church, including its substructure [18] (pp. 13-26). In Constantinople, the church known as Kalenderhane Camii has an interesting construction history involving numerous phases from Roman to the 13th century. One of the theories put forward by the investigation team involves a small (probably even private) Roman bath-house occupied by a 6th-century church which was eventually transformed into the 12th-century building that we see today [19] (pp. 31-36).

In Crete, a similar case is presented by the bath-house that was turned into the church of Hagios Demetrios in Viran Episkopi near Rethymno [20]. The overall conditions of this bath-house and its later fate is similar to the examples recorded in east Crete. Here, too, the complex is located close to a source of water-the river Arkadiotis-and the church is connected to a settlement called Episkopi. The similarity ends here, though, because the layout of the building is quite different. Another small bath-house of cross shaped plan was recorded by Gerola but more recent research could not identify 
its possible remains. This, too, has been connected to a much later church that was probably built on top of it. Yet both its exact location and its original dating are far from clear. The whole question of small bath-houses recorded by Gerola has been more recently explored by Kelly, in whose publication one can find the previous bibliography on the matter [21].

On the Cycladic island of Naxos, the conversion of a Roman bath into a small church was recently published [22]. In the church of Hagios Georgios, in Melanes, there is evidence of the materials, techniques and technology pertaining to its original use as a bath-house preserved in its fabric. It is situated in a ravine where it had ready-access to fresh water. It was transformed into a small chapel, although the dating of the conversion is far from clear. Apparently, the subject of baths converted to churches needs to be explored further and the publication by Kullberg ignores the instances we report here [17].

\section{Bath-Houses and the Settlements They Belonged to}

Returning to the subject of the bathing complex in Mochlos, one of the most important questions we are facing relates to its character: was it near a settlement and, if so, of what character? Since bathing in specially constructed buildings is considered a social phenomenon, it is only natural to question whether this bathing complex was in, or close to, a settlement. The question is far from simple since the placing of the bathing complex might depend, at least partly, on practical considerations. Therefore, even if it was connected to a settlement, it most probably was not placed at its center. Its placement in the lower part of a ravine can be explained by the need to collect water for its operation. If indeed it was connected to a settlement, it still may have been along its periphery. If the space occupied today by the small chapel of Hagios Andreas, a little further uphill to the east, was indeed a Christian Basilica, then this would certainly point to the existence of a settlement. In this scenario our bathing complex would serve this settlement's inhabitants. While its position would be in close proximity to its associated settlement, its site demonstrates a keener concern for access to fresh water, which could be stored in its cistern.

This observation can be applied to at least three other bath-houses recorded in east Crete where similar concerns for securing water supplies are evident $[23,24]$ (Figure 15). All three are of similar scale and layout, as well as building technique. On the other hand, they differ from the two bathing structures we have excavated in Loutres, since the other examples were converted into churches, thus preserving a great part of the original fabric in the church walls.

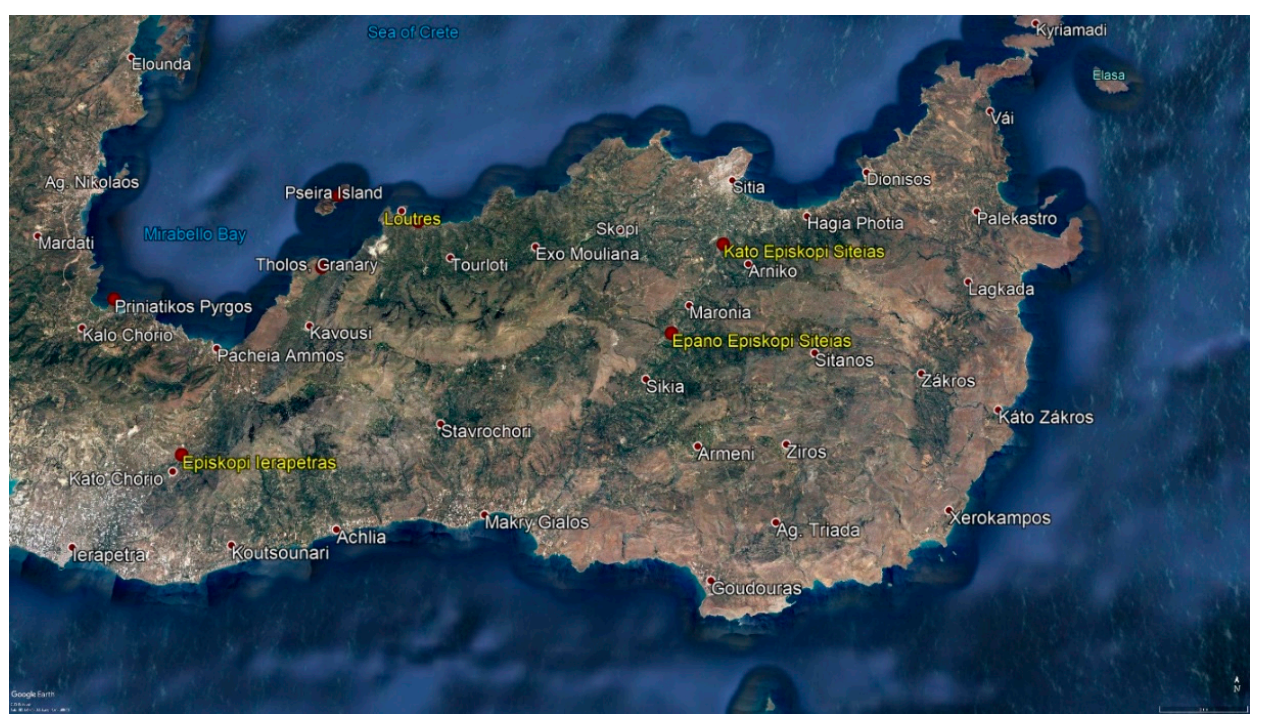

Figure 15. Distribution map of Byzantine cross-shaped bath-houses in Eastern Crete. (Source: Google Earth). 
All three are placed near ravines, a feature probably relating to the access of fresh water coming down from hills and mountains. Yet all are far from the sea, unlike the complex in Loutres and, therefore, if they served a settlement, this was also an inland one. Indeed, all three are related to settlements (today villages) that bear the highly suggestive name of Episkopi, a name that relates to bishoprics, an issue that we will discuss below. This could well be an indication for the existence of an important settlement, a town or city, which was the seat of a bishop. All three settlements are connected, both physically and through their name, to the big seaside cities of east Crete, Ierapetra and Siteia (Figures 16-18).

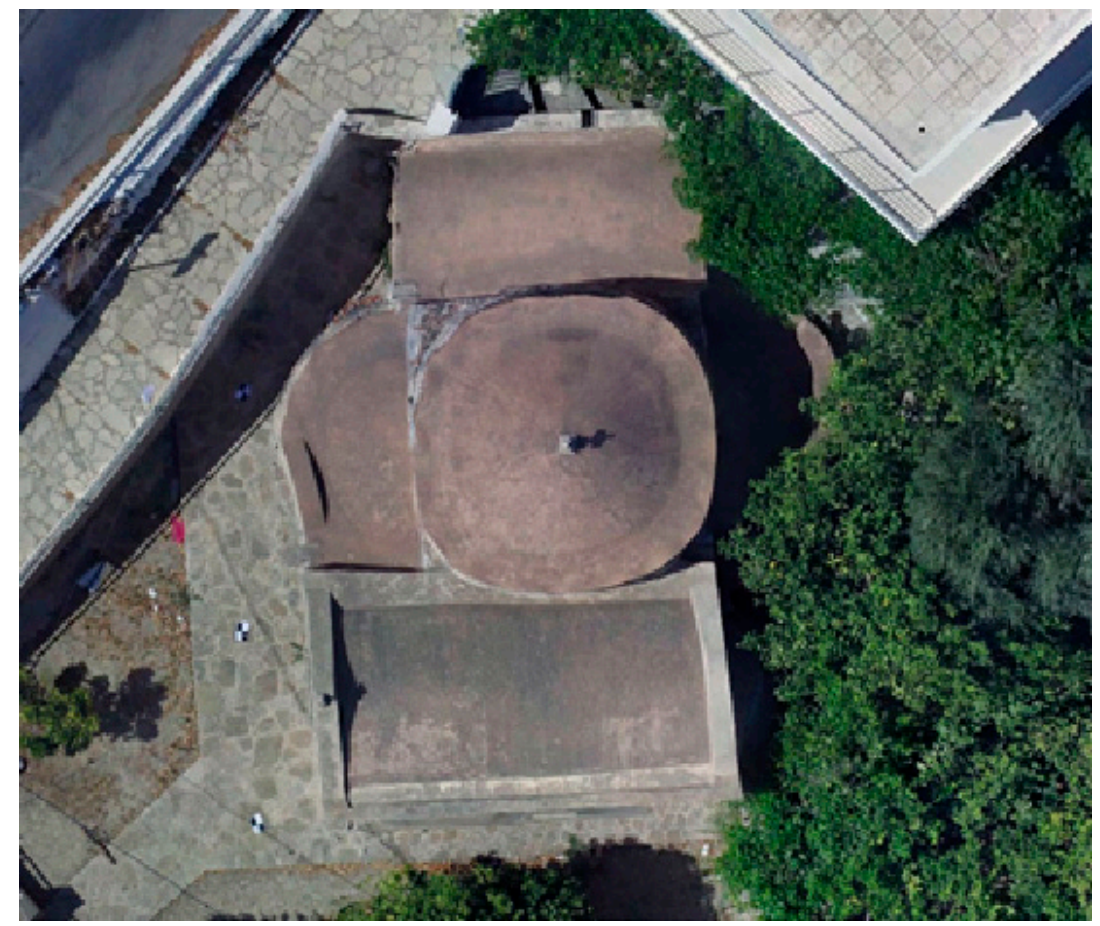

Figure 16. The cross-shaped bath-house converted into a church in Episkopi Ierapetras. (Photo: Ph. Stefanou).

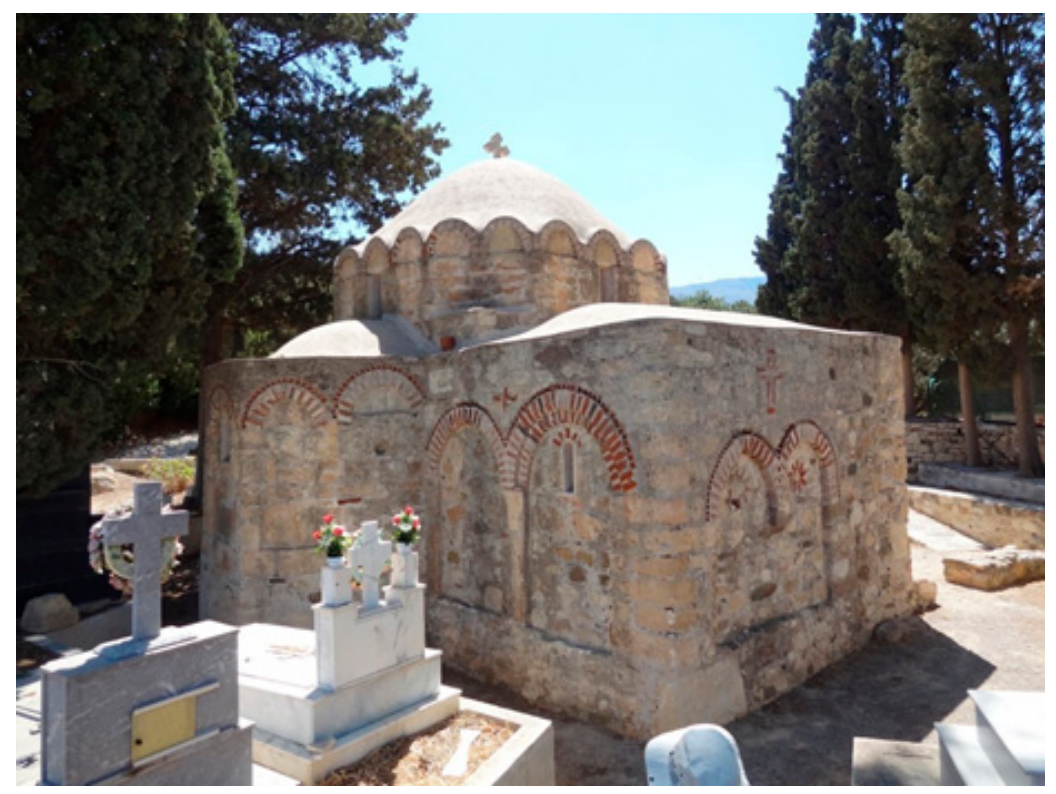

Figure 17. The cross-shaped bath-house converted into a church in Kato Episkopi Siteias. (Photo: Ph. Stefanou). 


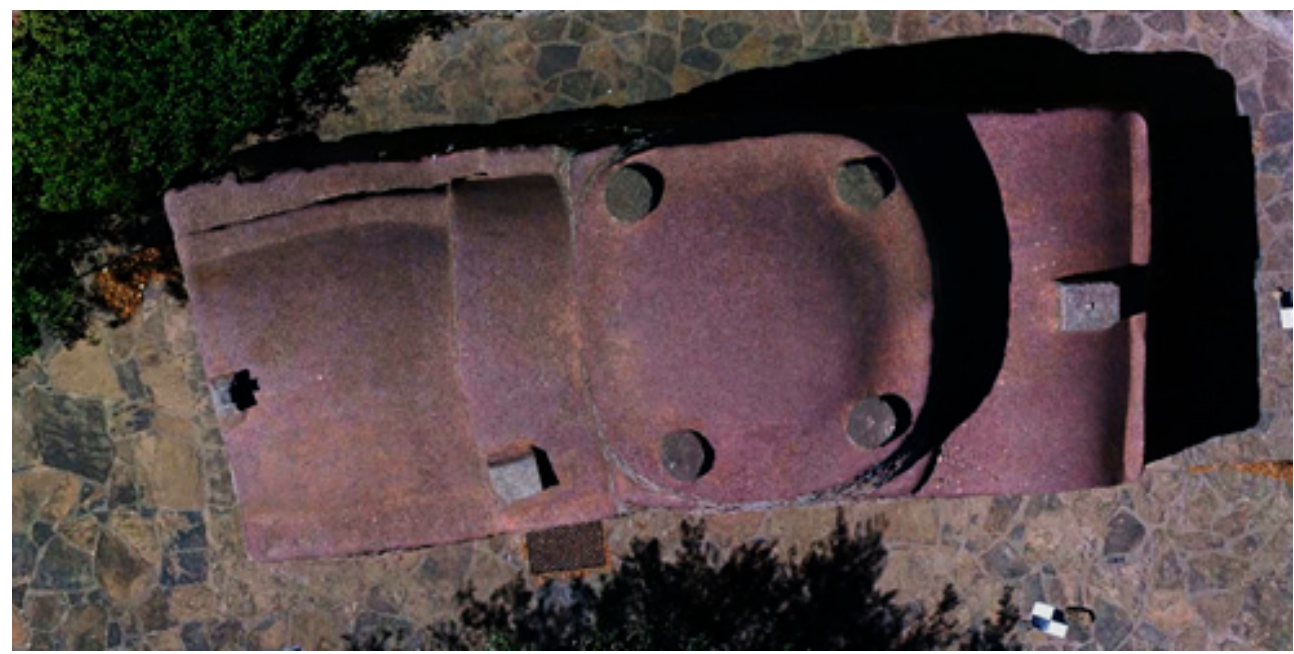

Figure 18. The cross-shaped bath-house (two cross arms now demolished) converted into a church in Epano Episkopi Siteias. (Photo: Ph. Stefanou).

The name of these settlements-Episkopi-is a subject that has been discussed by several scholars, although there is no consensus on its meaning. For some scholars the name Episkopi found in inland areas is indicative of the transference of the population, along with its institutions, away from the coast, during the second half of the 10th century, due to the so-called Arab threat. This theory purports that these inland villages were named Episkopi because they became the seats of local bishops. Unfortunately, this hypothesis is not based on evidence from the written sources and projects a simplistic view of the ecclesiastic and political situation of Middle Byzantine Crete. The name Episkopi could better be explained if applied to areas where the church held numerous land-holdings which were worked by the villagers, a model previously proposed by Poulou-Papadimitriou [25] (pp. 321-323) [26] (pp. 40-46) [27] (pp. 270-275, 290-293). This could explain also the modesty in terms of scale and lavishness of these churches that are rather small and relatively poor to be considered as Cathedrals befitting a bishop.

What remains striking is the fact that the three establishments associated with this toponym in east Crete were transformed into churches, thus preserving their structural integrity, in contrast to the installations at Loutres. All are cruciform and vaulted, while their central space is covered with a dome $[23,24]$. These characteristics relate to their original function, making them highly suitable structures for conversion into churches. The same characteristics (the cruciform layout and the centrally positioned dome) acquired a symbolic value that made them suitable for church structures. In the process of their conversion, several alterations were made, most notably in their wall surfaces. Two acquired extra decorations in the form of blind arcading, brick-work and rosettes, most conspicuously on their domes and the cross arms. These additions enhanced the original layout, composed of cross-shape and dome, and transformed the intrinsic character of the buildings.

Judging from details in their fabric, especially the brickwork and the rosettes, we propose that they functioned as bath-houses in the Middle Byzantine period and transformed into churches after the 13th century, when these details were added [6] (Figure 19). It should be noted here that Mylopotamitaki and Katifori proposed earlier conversion dates but presented unconvincing arguments [23,24]. Mylopotamitaki dated the rosettes to the Middle Byzantine period, while Katifori also viewed them as part of the original structure; if considered alongside the inlaid brick crosses, however, the rosettes would be more appropriately placed in an ecclesiastical structure, rather than read as part of a bath-house setting. Both the transformation and its dating present interesting questions regarding the buildings' functionality. 


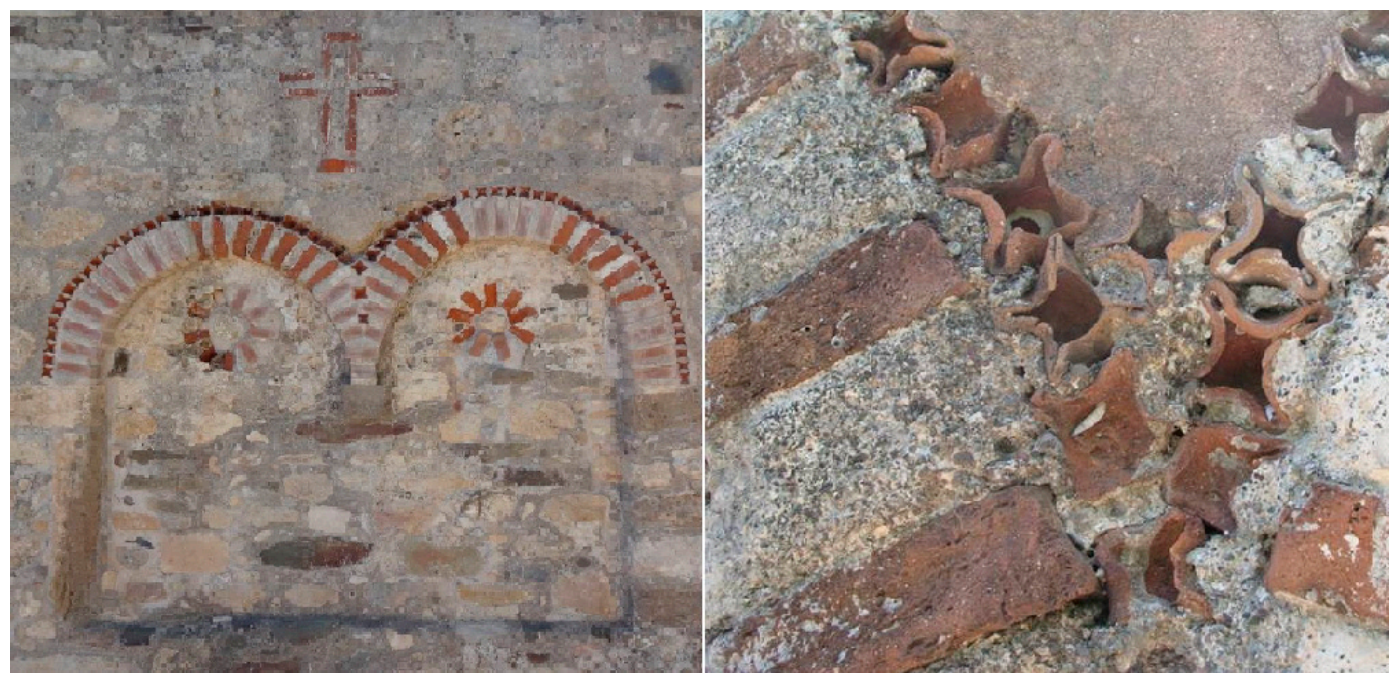

Figure 19. Detail of brickwork and rosettes on the facades of the Kato Episkopi Siteias church (bath-house). (Photo: A. Tantsis).

If the original bath-house structures served a settlement, it was most probably a rural one, the inhabitants of which would have been highly engaged in agricultural production in the inland plains of both Ierapetra and Siteia. As already noted, it remains unclear whether these bathing installations were located within the settlement, as their precise location seems to be more acutely determined by a need for water over any desire to be the focal point of inhabited space. The name Episkopi, shared by all three villages now, could be an indication that these were estates of the bishopric and the villages were formed by the people who were working on them. If this were the case, then these bath-houses were connected to a rural settlement and formed part of its infrastructure.

The bathing complex in Loutres near Mochlos is unique despite obvious similarities. Firstly, it is close to the shore, indicating that the settlement it catered for was also coastal. Since the bath-house seems to have functioned roughly from the 8th to the 12th century, this would strongly suggest that any associated settlement was also active during this period. Such activity strengthens the idea that even though the early middle ages are considered a period of hardship for Crete, due mainly to the Arab occupation of the island, its settlements, including coastal examples (as demonstrated here), continued to function. Narratives of Arab threat and piracy cutting off coastal communities and driving them from the shore persisted in the academic record for generations. The bathing complex at Loutres tells of a completely different story: one of continuity from the early middle to the late middle ages $[6,28,29]$ (pp. 140-141). Our archaeological investigations in Crete allow us to propose that by the mid-7th through the 8th century, while the existing urban fortifications were reinforced in whole or part, at the same time coastal installations were set up at spots suited to keeping watch over the sea-lanes. As argued elsewhere by the current authors, the fortification of insular defenses must have been integrated in a well-organized system under state control [28-30].

The change in function of these bath-houses in east Crete is proof both of a repurposing of fate for all structures discussed thus far and, by inference, their associated settlements. In the case of the bath-houses that were turned into churches, this is most probably an indication of the relevant settlements expanding and surrounding these structures that at first were placed outside of the settlements and close to the place of collecting water. We might also suggest that an increase of demographics of these settlements produced an increase for the demand of fresh water and thus bathing was catered for in another place or in other, yet even less lavish, structures. Thus, the old bath-houses with their cruciform domed layout were deemed suitable for church conversion.

In Loutres, on the other hand, there was probably periodically an abundance of water (this possibly explains the enlargement of the cistern to store water also on its periphery). The cistern was the only structure still visible on the site before we began our excavations. Even in the secondary transformation 
and function of this structural space, demand for water remained high, as substantial quantities of water were also needed for the operation of the ceramic kiln. This transformation tells a different story regarding the position and the nature of the settlement until up to the 12th century. The discovery of a double bath-house would point to the relative importance of the associated settlement, especially if we consider that these amenities were rare in the Middle Byzantine period. In contrast, its transformation into an industrial space may indicate a shift in settlement focus, as such production is often located at a remove from domestic contexts, at least in rural settlements.

\section{Conclusions}

Bath-houses could be associated with both inland and coastal settlements where they maintained a particular position within both their social and geographical environment. While they were constructed close to natural water sources, they were also located within, or close to, inhabited areas and, consequently, can be informative regarding the topography of rural or semi-urban settlement (in this case within the context of east Crete in the Middle Byzantine period). The fact that the bathing complex at Loutres is located on the coast refutes popular claims that the shoreline was abandoned before or during the Arab occupation; on the contrary, its position reinforces narratives of continued coastal habitation throughout the Byzantine periods.

The study of these bath-houses, their construction and transformation, sheds much light on the significant cultural changes that Crete experienced in the 13th century. The examples transformed into churches are most likely to reflect demographic change and cultural shift within their immediate environment. In the area of Loutres, the presence and later transformations of the baths reveal significant fluctuations within the local settlement pattern where the buildings themselves serve as a lens through which we can study demographic trends and social practice through time.

Author Contributions: N.P. and A.T. contribute on this article equally.

Funding: The research carried out so-far in the excavation in Loutres has received funding from the Research Council of the Aristotle University of Thessaloniki and a Project Grant by Dumbarton Oaks.

Acknowledgments: In the five years of our on-going excavation at Loutres, Mochlos, in east Crete, we have received generous support from several corporations and individuals. Aegean Airlines have provided us with help in transportation, LAVA has supplied small grants to assist with student accommodation expenses, INSTAP has been highly supportive of all our endeavors while we continue to enjoy the support of, and receive practical help from, the local community. Over the years several graduate and undergraduate students took part in the excavations and we thank them all for their help and enthusiasm.

Conflicts of Interest: The authors declare no conflict of interest.

\section{References}

1. Soles, J.; Davaras, C. Excavations at Mochlos 1989. Hesperia 1992, 61, 413-445. [CrossRef]

2. Leatham, J.; Hood, S. Sub-marine Exploration in Crete, 1955. BSA 1959, 53-54, 263-280.

3. Sanders, I.F. Roman Crete an Archaeological Survey and Gazetteer of Late Hellenistic, Roman and Early Byzantine Crete; Warminster: London, UK, 1982.

4. Vogeikoff-Brogan, N. Patterns of Mobility within a Site: Upper and Lower Mochlos. In Proceedings of the 12th International Congress of Cretan Studies, Heraklion, Greece, 21-25 September 2016.

5. Poulou-Papadimitriou, N.; Konstantinidou, S. Mochlos island in the Byzantine period. The Archaeological data. In Proceedings of the Fourth Cretan Meeting for the Archaeological Work in, Rethymno, Greece, 21-25 September 2016. (In Greek)

6. Poulou, N.; Tantsis, A. Notes on the Medieval Bath-houses of Eastern Crete. In Proceedings of the 12th International Congress of Cretan Studies, Heraklion, Greece, 21-25 September 2016. (In Greek)

7. Poulou, N. Archaeological Research at Loutres, Mochlos: Investigation of a Bath Complex of Medieval Crete. 2018. Available online: https:/ / www.doaks.org/research/support-for-research/project-grants/reports / 2016-2017/poulou (accessed on 25 August 2018).

8. Bonifay, M. Etudes sur la Céramique Romaine Tardive d'Afrique; Archaeopress: Oxford, UK, 2004.

9. Yegül, F. Bathing in the Roman World; Cambridge University Press: New York, NY, USA, 2010. 
10. Kelly, A. Roman Bathhouses on Crete as Indicators of Cultural Transition: The Dynamics of Roman Influence. In Creating Ethnicities and Identities in the Roman World; Gardner, A., Herring, E., Lomas, K., Eds.; Institute of Classical Studies University of London: London, UK, 2013; pp. 131-162.

11. Saradi, H. The Byzantine City in the Sixth Century: Literary Images and Historical Reality; Society for Messenian Archaeological Studies: Athens, Greece, 2006; ISBN 9789608755512.

12. Brogiolo, G.P.; Ward-Perkins, B. (Eds.) The Idea and Ideal of the Town between Late Antiquity and the Early Middle Ages; Brill: Leiden, Germany; Boston, MA, USA, 1999; ISBN 9789004109018.

13. Гoúv $\alpha \rho \eta-\sigma, \Gamma$. The Balneum and the Adjacent Spaces to the North of the Octagon in; Archaeology Society: Athens, Greece, 1990; ISBN 960703600X.

14. Cosentino, S. Episcopato e società a Kos tra IV e VIIIsecolo. In Archeologia Protobizantina a Kos: La Città e il Complesso Episcopale; Baldini, I., Livadioti, M., Eds.; Bononia University Press: Bologna, Italia, 2015; pp. 105-122, ISBN 9788869230196.

15. Chevalier, P.; Raynaud, M.-P.; Vanderheyde, C.; Wurch-Koželj, M.; Beaudry, N.; Muçaj, S.; Sodini, J.-P. Trois basiliques et un groupe episcopal des Ve-VIe siècles réétudiés à Byllis (Albanie). Hortus Artium Medievalium 2006, 9, 155-165. [CrossRef]

16. Feissel, D. Les édifices de Justinien au témoignage de Procope et de l'épigraphie. Antiq. Tardive 2000, 8, 81-104. [CrossRef]

17. Kullberg, J.B. When bath became church: Spatial fusion in late antique Constantinople and beyond. In Fountains and Water Culture in Byzantium; Shilling, B., Stephenson, P., Eds.; Cambridge University Press: Cambridge, UK, 2016; pp. 145-162, ISBN 978-1-107-10599-7.

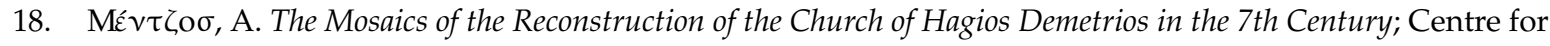
Byzantine Studies: Thessaloniki, Greece, 2010; ISBN 978-960-7856-40-1. (In Greek)

19. Striker, C.L.; Kuban, Y.D. Kalenderhane in Istanbul: Final Reports on the Archaeological Exploration and Restoration at Kalenderhane Camii, 1966-1978; Verlag Philipp von Zabern: Mainz, Germany, 1997; ISBN 3805320264 9783805320269.

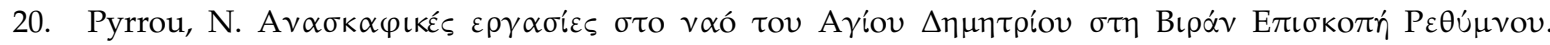
$\mathrm{T} \alpha \pi \rho \dot{\omega} \tau \alpha \alpha \pi \mathrm{\tau} \tau \boldsymbol{\varepsilon} \dot{\varepsilon} \sigma \mu \alpha \tau \alpha$. In Archaeological Works in Crete 1 (Excavations on the church of Hagios Demetrios in Viran Episkopi of Rethymno. First Report); Andrianakis, M., Tzachili, I., Eds.; Publications of the School of Philosophy of the University of Crete: Rethymno, Greece, 2010; pp. 543-555. (In Greek)

21. Kelly, A. Giuseppe Gerola's Strange Cretan Bagni. Creta Antica 2014, 15, 101-125.

22. $\mathrm{M} \pi \hat{i} \lambda \eta \varsigma, \Theta$. The transformation of a Late Roman bath-house into church. The case of the chapel of Hagios Georgios in Melanes in Naxos. In HERO BUILDER in Memory of CHARALAMBOS BOURAS; Mpirtacha, K., Korres, M., Mamloukos, S., Mallouchou-Tufano, F., Eds.; Melissa: Athens, Greece, 2018; Volume 2, pp. 229-241, ISBN 978960204375 2. (In Greek)

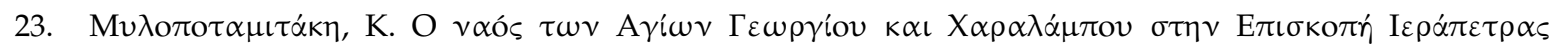
(The Church of Hagios Georgios and Hagios Charalambos in Epiksopi Ierapetras). $\Delta \varepsilon \lambda \tau i ́ o v$ in

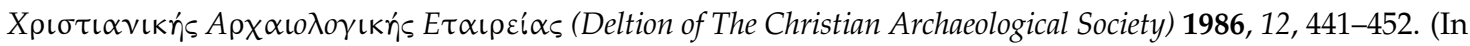
Greek) [CrossRef]

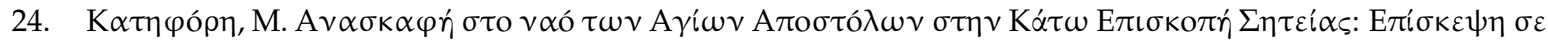

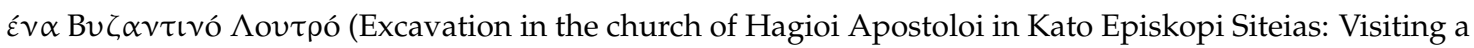
Byzantine bath-house). In Archaeological Works in Crete 1; Andrianakis, M., Tzachili, I., Eds.; Publications of the School of Philosophy of the University of Crete: Rethymno, Greece, 2010; pp. 211-222. (In Greek)

25. Poulou-Papadimitriou, N. Pottery of the middle Byzantine period and the first centuries of the Venetian occupation from Petras, Siteia. In Petras, Siteia, 25 Years of Excavation and Studies; Tsipopoulou, M., Ed.; Monographs of the Danish Institute at Athens: Athens, Greece, 2012; Volume 16, pp. 315-323.

26. Laiou, A. The Byzantine village (5th-14th century). In Les Villages Dans l'Empire Byzantine, IVe-XVe Siècle; Lefort, J., Morrisson, C., Sodini, J.-P., Eds.; Réalités Byzantines 11: Paris, France, 2005; pp. 31-54.

27. Lefort, J. The rural economy, seventh-twelfth centuries. In The Economic History of Byzantium: From the Seventh through the Fifteenth Century; Laiou, A., Ed.; Dumbarton Oaks Research Lib: Washington, DC, USA, 2002; pp. 231-310.

28. Poulou-Papadimitriou, N. Sea routes in the Aegean during the early Byzantine period: The ceramic's testimony. In Archaeology and Art in the Dodecanese during Late Antiquity, Eulimene 2; Zarras, N., Stefanakis, E., Eds.; Mediterranean Archaeological Society: Rethymnon, Greece, 2014; pp. 127-152. (In Greek) 
29. Poulou-Papadimitriou, N. Sailing in the Dark: Trade networks and commercial interaction between Crete and the neighboring islands in a period of transition. In The 8th Century. Patterns of Transition in Economy and Trade throughout the Late Antique, Early Medieval and Islamicate Mediterranean in Multidisciplinary Perspectives; Millennium: London, UK, 2018.

30. Poulou-Papadimitriou, N. Hagios Georgios of Vouno. The Byzantine and early Venetian periods. In Hagios

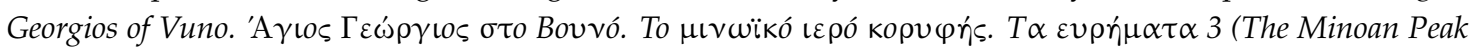
Sanctuary. The Findings 3); Sakellarakis, Y., Ed.; The Archaeological Society at Athens: Athens, Greece, 2013; pp. 25-266. (In Greek)

(C) 2018 by the authors. Licensee MDPI, Basel, Switzerland. This article is an open access article distributed under the terms and conditions of the Creative Commons Attribution (CC BY) license (http:/ / creativecommons.org/licenses/by/4.0/). 